\title{
The effective ways of promoting the construction of campus culture through university library
}

\author{
Gemin Li \\ Jilin Agricultural University, Changchun 130118, China \\ 308420502@qq.com
}

\begin{abstract}
University library is an important part of campus culture construction, while campus culture construction of university cannot carry out without the effective advancement of library. This paper focused on the ways of university library's improvement of campus culture construction. Through those ways, the construction of campus culture can be effectively promoted.
\end{abstract}

Keywords: university; library; campus culture; construction.

\section{Introduction}

The construction of campus culture is a great responsibility of the University. Library as one of the pillars of the campus culture, its importance is self-evident. Every university has a library, the characteristics of the library has always become a topic for the students to talk about. From the perspective of the construction of campus culture, the position and function of the library is unparalleled. As the construction of campus culture is an interactive process, so how to play the role of the library in the campus culture has become a focus of attention of the university library management

The university is an important part of the social organism, is the cradle of colleges, and is an important position in the construction of a harmonious society. And the university library is the base of knowledge transmission. It is the center of document information security, and is one of the pillars of the University. Also it is the second classroom of university teachers and students. It plays the function of spreading civilization and shaping the soul. And it plays a very important role in the construction of campus culture.

\section{The connotation of campus culture}

Campus culture is a unique culture formed in the process of historical development. It is the reflection of social culture in university campus. It is an important embodiment of the spirit of the university, and it is also called the soul of the university. It is a brand, a university's cultural and educational power. Healthy and beautiful campus culture can not only provide a physical and psychological "magnetic field" to the teachers and students, but also can give the invisible education charm to all teachers and students and make them enjoy in this kind of environment. In the campus culture, staff and students is regarded as its subject, the campus as its space, university spirit as a guide. And campus activities as the main content. It is the highest goal, value concept, thinking mode and behavior standard of teachers and students. Campus culture is divided into material culture, system culture and spiritual culture. Material culture is the outer performance of the campus culture. The system culture is the institution of university organization and its rules and regulations. Spiritual culture including motto, school spirit, style of study, school spirit and guiding principle for running a school, is the core of campus culture. Campus culture is a kind of management culture, education culture and organization culture. It reflects the cultural identity and living conditions of teachers and students. It is a kind of spirit, a kind of strength, a kind of connotation and a kind of charm.

\section{The task of the construction of campus culture}

In the campus cultural activities, there are many ways to obtain the knowledge of teachers and students. They often make dynamic adjustments based on the formation and transfer of hot spots. 
Campus culture should provide opportunities for teachers and students to meet the learning interest and ignite the spark of wisdom which can promote the development of teachers and students' active thinking and intelligence. Rich campus cultural activities can stimulate the students' non intelligence factors and students' interest in learning. Through creating a good cultural atmosphere, it can improve the overall cultural literacy of teachers and students and their knowledge structure as well.

The influence of the university to the teachers and students is not only the teaching of the specific knowledge, but also the influence of the culture. This is an atmosphere on campus sprite and learning style in the university. This is a kind of life attitude, value orientation, ideological quality and behavior habit in the campus life. This culture is not something that someone can teach them. It exists in the campus culture atmosphere. It is integrated into the soul of teachers and students, and it is internalized into a humanistic quality and character of them, to lay a solid foundation for the healthy growth and all-round development.

\section{The relationship between university library and the construction of campus culture}

\subsection{University library is the main position of the construction of campus culture}

University Library, as the literature information center of the University, is one of the three pillars of the university personnel training, and is the main position of the construction of campus culture. Library not only provides rich literature resources for the construction of campus culture, but also provides a good environment for the activities, creating a broad space for development. Library is not only a treasure house of knowledge, but also an orderly collection of culture. Library provides the literature information resources for the teaching and scientific research, and provides the position for the campus culture construction, and has fully played the function of teaching, information transmission and so on. Library enables teachers to prepare lessons, scientific research projects and academic exchanges effectively. It is the link and place for the young students' extracurricular study, knowledge consolidation and other activities. It is also the information input window of campus spirit culture system, which has profound influence on the spirit.

\subsection{The construction of campus culture in colleges and universities cannot be separated from the effective promotion of the library.}

The construction of campus culture is a complicated system engineering, which needs the strong support of all functional departments of the school, especially the effective promotion of the library. Library reading activities and other forms of educational activities in the library are different from the general knowledge process in the classroom. It is more like is a kind of ideological influence and influence process. It affects the overall development of nuanced young students while other kinds of teaching methods are unable to reach the realm. At the same time, the library construction of the book collection is not only for the school's professional setting and discipline development organization collection, but also combined with the comprehensive quality of young students to cultivate and the needs of campus culture construction. Universities need to establish a scientific and reasonable library collection system which is suitable for the training of talents in universities to promote the all-round development of young students and promote the effective development of campus cultural activities. Therefore, in the aspects of creating a good campus cultural environment, training young students' comprehensive quality and ability cannot be separated from the effective promotion of the library.

\section{The way to effectively promote the construction of campus culture in university library}

The campus culture is a subsystem of the social culture, and it is the embodiment of the spiritual civilization. It has a far-reaching impact on young people, and even affect their whole life. However, the library in promoting the construction of campus culture, is not a short duration of time to complete, it needs from many aspects. In promoting the construction of campus culture, this paper should mainly focus on the following points. 


\subsection{The construction of their own hardware conditions}

Hardware conditions of the library includes not only the construction style of library and library resources abundant, but also includes the layout settings. There are often some study rooms in the university library. During the exam, the study room is often not enough, but usually there are not so many people. Therefore the number and the opening of the library study room should keep a variable according to the situation. In addition, setting up a cafe in the library is becoming a trend. Convenience stores and stationery shops are constantly appearing which makes the library become more convenient for the readers.

\subsection{Focus on the quality of library personnel training}

Library staff is the builder of the library, the direction of library development and library management staff are closely related. The professional and service of the librarian directly affects the construction of the library. University library should gradually improve the quality of the library management staff towards the direction of professional development, and constantly improve the level of library. The other focus should be the culture of library service quality. At the same time it can stop illegal behavior in the library and care for students.

\subsection{Initiative to launch cultural activities on campus}

When freshmen is in the use of the library, they often appears to be relatively unfamiliar. Therefore, the library should offer relevant guidelines issued for the freshmen and make them understand the function and requirements of the library. In terms of resource retrieval, the library should carry out regular lectures and training, so that the majority of teachers and students can make more full use of the resources of the library. In the usual after-school activities, the library can also initiate some activities, such as reading the classic activities, essay contest, love book signing, donating books and other activities, which can let the students join the library activities.

\subsection{Cooperate with teachers}

Library as an extension of the university classroom, should understand the needs of students, which requires the cooperation with the department of teachers. According to the training requirements of the teachers in the department, the library should try their best to meet the requirements. It can make the students obtain the knowledge in class and strength it after class. The combination of classroom and extracurricular, can help students better.

\section{Summary}

Library, as the heart of the University, is an important symbol to measure the strength of a university. All the famous universities in the world have excellent library culture. With its rich cultural resources, elegant atmosphere and quality service, the library promotes the development of campus culture. Creating a library with a pleasant environment, perfect infrastructure and rich information resources has a decisive significance for the development of campus culture.

\section{References}

[1] Li Xudong. The effective ways of promoting the construction of campus culture of university library [J]. Journal of Henan Institute of Science and Technology. Vol. 7(2012) No.7.

[2] Ma Weixiang, Sun Hongyan. On the Participative Functions and Ways of College Librariesin the Construction of Campus Culture [J]. Journal of Weifang Educational College, Vol. 18(2005) No.4.

[3] Jin Jianjun. Giving Play to the Superiorities of University Library to Promote the Construction of Campus Culture [J]. SCI- TECH INFORMATION DEVELOPMENT \& ECONOMY, Vol. 18(2008) No.12.

[4] Hu Xuan. Talking about How University Library to Promote The Construction of Campus Culture [J]. SCI- TECH INFORMATION DEVELOPMENT \& ECONOMY, Vol. 24(2014) No. 3. 